УДК 811.161.2'373

I. Є. Іншакова

\title{
ПРОБЛЕМА ДОСЛІДЖЕННЯ ЗАПАХУ В НАУКОВІЙ ЛІТЕРАТУРІ
}

Іншакова I. Є. Проблема дослідження запаху в науковій літературі.

Вивчення семантичних груп словникового складу мови $є$ традиційним в українському мовознавстві. Повне дослідження історії лексичного складу української мови неможливе без з'ясування історії формування окремих семантичних груп. Статтю присвячено проблемі дослідження одоративів у науковій літературі.

Ключові слова: запах, сприйняття, сенсорика, нюх, аромат, лексика, одоративний складник.

Иншакова И. Е. Проблема исследования запаха в научной литературе.

Изучение семантических груп словарного состава языка является традиционным в украинском языкознании. Полное исследование истории ๑ І. Є. Іншакова, 2016. 
лексического состава украинского языка невозможно без выяснения истории формирования отдельных семантических групп. Статья посвящена проблеме исследования одоративов в научной литературе.

Ключевые слова: запах, восприятие, сенсорика, нюх, аромат, лексика, одоративная составляющая.

Inshakova I. Y. The problem of odor research in the scientific literature.

Different perceptions definition explains the diversity of approaches and specific industry that it is considering. Problems of perception actively investigated physiologists, psychologists, philosophers. Aroma in European culture analyzed in the works of cultural history, aesthetics, linguistics, literature. Odor is the subject of a number of research disciplines: philosophy anthroponymy, philosophy, culture, education, psychology, psychophysics, medical practice. Scientists investigating the phenomenon as a cultural flavor component odoratyvnoho segment of the world, forms its sensory representation peculiarities of perception and information odoratyvnoyi in European culture, science and philosophy.

The authors consider the whole system of perception and of particular relevance to smell like a promising direction and interpret flavor not only as an aesthetic phenomenon, but as a «spiritual» segment of the culture of the nation. The matter well represented in a number of scientific studies in the field of linguistics, art. Uzayemopronyknennya explains different types of art practice synestetychnoho use the vocabulary of the senses. This helps in the interpretation of olfactory marks, recognizing odoratyvnyh meaning that enriches human understanding of the world. Smell - a particular property of this or that reality is reflected in modern minds through the olfactory sensations. His influence, a variety of experiences reflected in the language. In the scientific literature odor understood as a feeling that arises during the odorous substances to the receptors of the mucous membrane of the nasal cavity. Characteristic odor usually served by a substance that causes this feeling.

Key words: odor perception, sensing, smell, flavor vocabulary odorativity component.

За наявності низки мовознавчих робіт, що аналізують лексику відчуттів, відсутні в лінгвістиці дослідження, грунтовані на системному описі одоративної лексики. Вивчення лексики запаху є перспективним i актуальним, бо дає змогу ширше подати загальномовну картину світу. Висвітленню проблем дослідження запаху в науковій літературі присвячена наша стаття.

Довкілля людина осягає за допомогою зовнішніх чуттів: зору, слуху, дотику, смаку, нюху. Дослідниками доведено, що всі запахи емоційно забарвлені, можуть впливати на перебіг думок (А. Бронштейн, В. Гулімов, А. Дроботун, А. Мінор, С. Рязанцев). 
Сенсорику людини розглядали ще Аристотель, Платон, Фома Аквінський. Характеристики чуття $з$ погляду його впливу на естетичне сприйняття світу аналізували М. Пруст, Ю. Лотман. Різні визначення поняття сприйняття пояснюються розмаїттям підходів і специфікою галузі, яка його розглядає. Проблеми сприйняття активно досліджували фізіологи, психологи, філософи: Н. Бернштейн, П. Гальперін, Д. Гібсон, М. Мерло-Понті, I. Сеченов, Н. Соколов, М. Хайдеггер та ін.

Сутність процесів чуттєвого й раціонального пізнання людиною довкілля вивчали Б. Ананьєв, Г. Костюк, О. Леонтьєв, вплив ароматів на психофізичний стан людини досліджували $\mathrm{B}$. Аршанський, С. Гамаюнов, Л. Дудченко, Н. Макарчук, Н. Холодний та ін.

Вітчизняні та зарубіжні дослідники розглядають одоративний складник довкілля та його вплив на людину. Аромат у європейській культурі проаналізовано у працях 3 історії культури, естетики, мовознавства, літературознавства, філософії (Р. Барт, Г. Башляр, О. Бурова, І. Ільїн, Р. Інгарден, Н. Кемпбелл, Д. МакКвін, В. Малахов, Ц. Тодоров). Запахи є об'єктом досліджень низки наукових дисциплін: філософської антропонімії та філософії культури (Є. Жирицька, Г. Кабакова, Р. Кірсанова, О. Кушліна, О. Левінсон), педагогіки, психології, психофізики, медичної практики (С. Вічканова, Л. Гейхман, Л. Жубер, Г. Заварзін, С. Іванов, А. Кедам, А. Малєєв).

Останнім часом з'явилося багато праць, присвячених аналізу феноменів культури в різні історичні епохи на власне історичному матеріалі, текстуальному (на матеріалі художньої літератури). Експериментальні дані, результати психотерапевтичних спостережень використовуються в дослідженнях особливостей функціонування тієї чи тієї системи сприйняття.

Культурна сенсорика сьогодні викликає зацікавленість, оскільки деякі органи чуття, зокрема нюх, часто лишаються поза увагою дослідників. Через фізіологічні, культурні традиції нюх в історії людства було витіснено «на периферію» й віднесено до «тваринних» відчуттів, віддаючи перевагу зору, слуху. Можливо, причина розташування нюху в 
сенсорній системі на нижніх щаблях пояснюється тим, що він генетично був найдавнішим з усіх наших чуттів, «...мав перевагу на ранній стадії розвитку людини, коли іï мудрість була мудрістю нюху...» [3, с. 25]. Ієрархічний поділ на «високі» й «низькі» чуття, «тваринне» та «людське» в різні епохи спричинив до приниження сенсорики нюху, хоч новонароджені передовсім використовують нюх та смак. Значна роль нюху в наявності тваринного інстинкту статевої орієнтації. Це дає змогу відносити нюх до розряду архаїчних. Теорія безпосереднього сприйняття дає право розглядати нюх поряд із зором та слухом.

С. Корчова-Тюріна в дисертації досліджує феномен аромату як культурний складник одоративного фону навколишнього світу, форми його сенсорної репрезентації, особливості функціонування i прийняття одоративної інформації в європейській культурі, науці й філософії. Автор стверджує, що «нюх здатен сам не тільки добудовувати інформацію, що сприймається, до стану цілісності, але й сприяти трансляції і транспортації культурних смислів» [3, с. 6].

Сучасна філософська антропологія та філософія культури загалом розглядають систему сприйняття й особливе ставлення до нюху як перспективний напрямок. Це дає змогу інтерпретувати аромат не тільки як естетичний феномен, але i як «духовний» складник культури нації. Уявлення про архетипні прасимволи, позачасові символічні схеми використовували дослідники для вивчення національних феноменів культури, історії, буття (М. Баткін, П. Гуревич, Ю. Лотман, Ц. Тодоров).

С. Корчова-Тюріна розширює тлумачення поняття аромату й подає його як «смислоутримувальний інваріант, який проходить через увесь розвиток національних культур і світової цивілізації» [3, с. 11]. Зокрема, філософ наголошує на сакральності протягом століть у культурі різних народів ароматів ладану, мирри, троянди. Смислом наповнювалася й сама наявність аромату, штучного запаху.

В одному з розділів дисертації С. Корчова-Тюріна аналізує практику використання нюхової лексики в тексті Біблії, поемах Гомера, 
художній літературі XIX-XX ст. і робить висновок про бідність запахової лексики, хоч наголошує на давній традиції трансляції смислів того чи того аромату, зокрема, у Гомера аромат постає як посередник між світом земним інебесним, за певним запахом закріплюється «божественна» значущість. У християнстві ароматом ладану позначається простір церкви, мирри - тіла людини в лоні християн. Саме християнство «виділило ладан і мирру з розряду повсякденних смол i надало їхньому аромату божественного статусу», тобто християнство відокремило сакральні запахи від земних і провело межу між запахом гріховним і божественним ароматом [3, с. 30]. Дослідниця підтверджує гіпотези про смисловий зміст і хронологічну зміну смислу аромату текстами Гомера, античної поезії та літератури, творами письменників XVIII-XX ст. (I. Крилова, О. Пушкіна, Л. Толстого, Т. Шевченка, М. Пруста, Д. Джойса, П. Зюскінда).

У літературних творах, живописі XIX-XX ст. запах почав протиставлятися зоровим і звуком образам. М. Россіянський у 1913 р. зазначав: «Поетичний твір є сполучення не стільки слів-звуків, скільки слів-запахів» [3, с. 30]. Маловивчена природа запаху, його невидимість закріпили за ним ознаку таємного, архаїчного, того, що відповідає етимології («запах» - те, що приховано, запахнуто, перебуває у складці за пахом). Це голос плоті, неповторний, оригінальний.

Філософ досліджує аромат як прасимвол окремої епохи й указує на трансформації аромату: здавна ароматичні речовини використовували з ритуальною, магічною метою; в античності ароматичні речовини виконували косметичну функцію, у новий час людина закріплює індивідуальність особистим ароматом: «Смисл парфумного запаху - бути іншим, можливість бути новим кожен день, приміряти на себе «нюхові маски» [3, с. 34]. Аромат тіла був знаком «культурності», соціального статусу, достатку, особистого смаку.

Одоративний складник довкілля в мові, мистецтві розглядали
М. Велер,
В. Виноградов, Ж. Деріда,
В. Дятчук,
Ю. Лотман,
О. Потебня,
В. Сидельников. Роботи
В. Дятчука
присвячені

() І. Є. Іншакова, 2016. 
розглядуваній проблемі в українській мові. Методику вивчення одоративної групи в роботах згаданих авторів, аналіз ними матеріалу на лексичному, граматичному, комунікативному рівнях використовує в дослідженні С. Корчова-Тюріна. Комунікативну роль запаху аналізує Г. Зіммель у роботі «З «Екскурсу про соціологію чуттів», де стверджує, що соціальне питання $є$ не тільки питання етики, але й питання носа [3, с. 12].

На нашу думку, заслуговує на увагу звернення філософа до проблеми трансляції одоративних символів на основі живопису. Дослідниця погоджується з Ю. Лотманом, який грунтовно проаналізував способи передачі одоративної складової на картині, що інструментарій митця не передбачає можливість передачі аромату, проте він провокується мистецтвом: глядач «добудовує» одоративний фон. Зокрема, науковець звертається до натюрморту як форми живопису.

Узаємопроникнення різних видів мистецтва пояснює практику синестетичного використання словника органів чуття. Це допомагає в тлумаченні нюхових знаків, розпізнанні одоративних смислів, що збагачує людське уявлення про світ.

Людина здатна розрізняти величезну кількість запахів та втримувати в пам'яті їх і міцно пов'язувати з тими чи тими подіями життя. Для передавання розмаїття запахів існує недостатня диференціація при вербалізації, що робить запах парадоксальною дійсністю [4, с. 6].

Запах - конкретна властивість тієї чи тієї реалії, яка в сучасній свідомості віддзеркалюється через нюхове відчуття. Його вплив, різноманітність відчуттів відбивається в мові [1, с. 36]. Часто в науковій літературі подається тлумачення запаху як відчуття, що виникає при дії пахучих речовин на рецептори слизової оболонки носової порожнини. Зазвичай запахи характеризуються через речовину, яка викликає це відчуття.

Перші класифікації запахів 3'явилися ще в період античності. 3 погляду психології, авторами найвідоміших класифікацій запахів $є$ 
Ч. Шерінгтон, Цваардемакер, Крокер і Хендерсон, 3. Хенінг. На жаль, жодна 3 класифікацій не стала еталоном через суб'єктивізм. «Визначення місця запахових відчуттів у житті людини має суб'єктивний характер. Так, кожен дослідник у міру розвитку в нього гостроти запахового відчуття, відводить останньому певне місце в житті людини», - зазначала С. Корчова-Тюріна [2, с. 72]. Обмеженість мовних засобів, що використовує людина при описі запаху, спричинила відсутність класифікації, подібної класифікаціям кольорів. Ханс Д. Риндисбахер зазначає: «У людській комунікації світ запахів має біполярну структуру, і простір між цими двома полюсами практично порожній» [5, с. 587]. Водночас одоративна лексика $€$ предметом сучасних лінгвістичних досліджень.

Отже, на сьогодні залишаються нез'ясованими проблемні питання, незважаючи на широкий спектр наукових дисциплін (фізіологія, психологія, культура, мистецтво, філософія, педагогіка, медична практика та ін.), що розглядають одоративний складник сенсорної лексики. Вивчення часткових аспектів розглядуваної лексики в українській, російській лінгвістиці, психолінгвістиці висувають потребу грунтовних досліджень, які узагальнювали б теоретичні й практичні напрацювання.

\section{Література}

1. Дятчук В. Семантична структура $\mathrm{i}$ функціонування лексики української літературної мови / В. Дятчук, Л. Пустовіт. - К. : Наукова думка, 1983. - 156 с.

2. Корчова-Тюріна С. Проблема маргінальних форм в європейській культурній сенсориці : дис. ... канд. філос. наук / С. Корчова-Тюріна - Харків, 2001. - 223 с.

3. Корчова-Тюріна С. Проблема маргінальних форм в європейській культурній сенсориці : автореф. дис. ...канд. філос. наук [Електронний ресурс] / С. КорчоваТюріна. - Харків, 2001. - Режим доступу : http://disser.com.ua/contents/8267.html

4. Павлова Н. С. Лексика с семой «запах» в языке, речи и тексте : дис. ... канд. филол. наук / Н. С. Павлова. - Екатеринбург, 2006. - 210 с.

5. Риндисбахер Х. От запаха к слову : моделирование значений в романе Патрика Зюскинда «Парфюмер»; пер. Я. Токаревой / Х. Риндисбахер // Ароматы и запахи в культуре. Кн. 2 / Сост. О. Вайнштейн. - М. : Новое лит. обозрение, 2003. - С. 583-611. Стаття надійшла до редакиії 26.08.2016 p.

С І. €. Іншакова, 2016. 